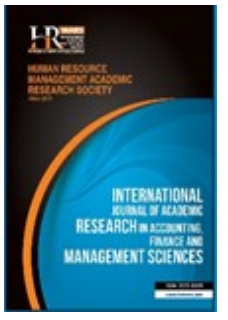

International Journal of Academic Research in Accounting, Finance and Management Sciences

Vol. 9, No.3, July 2019, pp. 49-58 E-ISSN: 2225-8329, P-ISSN: 2308-0337

(c) 2019 HRMARS

www.hrmars.com

To cite this article: Pop, I.-D. (2019). Systemic Sustainability of European Banking Activity: A Multi- Perspective Approach, International Journal of Academic Research in Accounting, Finance and Management Sciences 9 (3): 4958

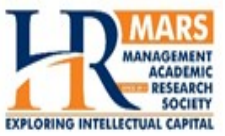

http://dx.doi.org/10.6007/IJARAFMS/v9-i3/6326 (DOI: 10.6007/IJARAFMS/v9-i3/6326)

\title{
Systemic Sustainability of European Banking Activity: A Multi- Perspective Approach
}

\author{
Ionuț - Daniel Pop \\ The Bucharest University of Economic Studies, 010961 Bucharest, Romania, E-mail: ionut.pop@fin.ase.ro
}

Abstract This paper proposes a multi - perspective approach for testing the banking sustainability in Europe, with a focus on the relationships between economic cycles, stock exchange market evolution and banking risks. More precisely, we examine the key drivers of banking profitability, non-performing loans rate, system solvency and economic growth based on banking and macroeconomic information. Our empirical analysis reveals the limitations of the existing risk models when it comes to efficiently identifying the main factors that generate massive losses for the banking industry. We report robust estimates indicating that capital level for covering banking risks should be increased. Furthermore, we bring strong empirical evidence revealing that capital market evolution exerts an important impact on banking stability. Our findings have serious policy influences and our proposals are made up of adjustments on the current European regulatory laws. In our opinion, national and European authorities should consider similar multi - approaches for banking risk evaluation in order to make relevant decisions that will eventually prevent further financial crises.

Key words Banking Sustainability, European Banking Systems, Risk Management, Panel Effects, Regulatory Policies Received: 29 July 2019 (c) The Authors 2019

Revised: 15 Aug 2019 Published by Human Resource Management Academic Research Society (www.hrmars.com)

Accepted: 19 Sept 2019 This article is published under the Creative Commons Attribution (CC BY 4.0) license. Anyone may Published Online: reproduce, distribute, translate and create derivative works of this article (for both commercial and non-commercial purposes), subject to full attribution to the original publication and authors. The full terms of this license may be seen at: http://creativecommons.org/licences/by/4.0/legalcode

\section{Introduction and Literature Review}

During the last decade, the global economic crisis has turned into the deepest recession in the European Union's history. There is no doubt that the recent economic downturn affected all member states; however, the impact was more visible in countries were the financial system had large structural problems. The first signs occurred with the debt crisis of Greece and continued on the same line with Italy, Spain and Portugal. Under those circumstances, twelve countries have decided to cut wages for the public sector employees. Furthermore, according to the European Commission (EC), during the recent financial turmoil, an amount of 600 billion EUR (4.6\% of 2012 European GDP) was provided to the banking sector in order to restore financial stability. Finally, the BREXIT offered a full picture of a divided Europe which still has a lot to improve in terms of financial sustainability.

Although the topic has been largely debated by scholars and practitioners, there is still a growing body of literature devoted to investigating banking sustainability. The financial risks evolution, the structure of the balance sheet, the profitability and the solvency related with the credit institutions were subjects addressed under this area of research. However, most of the aforementioned analyses followed a single topic and ignore the interdependencies between multiple banking variables or macroeconomic ones.

Even though banking risks are extremely diversified, most of the empirical studies are devoted to accurately quantifying credit risk. For example, Duffie and Singleton (2003) offered a theoretical analysis which illustrates its crucial importance in maintaining the health of the banking system. Later on, the probability of default inferred from binary methods was used as a proxy for the evolution of credit risk, as 
Gómez-Fernández-Aguado et al. (2018) explained. Moreover, in recent years, the rate of non - performing loans (NPLs) became a commonly used measure for this type of risk. Consequently (Kauko 2012; Louzis et al. 2012; Makri et al. 2014; Erdinç and Abazi 2014) have explored the most important factors affecting the level of NPLs. In addition, credit risk models included several determinants of NPLs from both microeconomic and macroeconomic perspectives, by using data from developing or developed markets. Such approaches were proposed by Guidara et al. (2013) for Canadian banks, Louzis et al. (2012) in Greece banking system or Erdinç and Abazi (2014) for 20 emerging countries around Europe. Regardless their empirical value, none of these researches took into consideration a large database containing all European Union countries. The only exception is given by Eichler and Maltritz (2013) which tested a credit risk model for Euro Zone area by including only macroeconomic variables. In addition to this exclusion, a database with all EU members is used to investigate the determinants of customer experience index by Barbu and Boitan (2018) using similar macroeconomic and bank-related indicators as our paper.

As current findings of credit risk models presented in (Dimitrios et al., 2016; Brad et al., 2013; Makri et al., 2014) have revealed, the existence of a negative relationship between banking profitability and the level of unpaid loans ratio is valid for both short and long terms. Likewise, the non-compliance with the bank capital adequacy's requirements exerts a negative impact on credit risk management as (Makri et al., 2014; Ghosh, 2015) explained. In this context, a capital buffer in conjunction with economic cycle and restrictive macro prudential policies were suggested by Guidara et al. (2013) on Canadian banks and (Gao et al. 2019; Zhang et al. 2018) for the Chinese ones. Moreover, the capital structure of Deposit Money Banks listed on Nigeria Stock is presented in relation with firm characteristics by Okegbe et al. (2019). The capital structure topic was extended to corporate performance of Romanian listed companies by Moscu (2014). Afterwards, significant relationships between macroeconomic variables like budget deficit, stock prices, exchange rates, taxation earnings, unemployment rate and different credit risk proxies were brought to light by (Kauko, 2012; Louzis et al., 2012; Salas and Saurina, 2002; Murarasu and Bobasu, 2014; Anghelache and Oanea, 2014; Anghelache and Oanea, 2016; Umaru et al., 2018; Jaradat and ALkhazaleh, 2018). Furthermore, a strong reverse relationship between economic growth and NPLs was highlighted by (Erdinç and Abazi, 2014; Makri et al., 2014; Fiala and Havranek, 2017). In addition, different perspectives, like introducing stock exchange market evolution indicators, were connected to the evolution of banking sustainability. In this respect, different features for European listed banks were analyzed by (Cepoi and Toma, 2016; Damian and Cepoi, 2016).

The aim of this paper is to investigate the concerning situation of European banking sustainability by introducing a multi-perspective view on the banking risk, banking profitability and macroeconomic trends. In this respect, the present study contributes to existing literature in several ways. First of all, we extend the empirical work presented in Eichler and Maltritz (2013) by using a larger database which incorporates information from all European Union member states. We follow this direction driven by the major policy involvement brought by European Central Bank (ECB) and European Banking Authority (EBA) regulations. Second, we introduce a multi - perspective approach meant to clarify the strong relationship between banking profitability, solvency, credit risk and the economic evolution. In contrast with (Erdinç and Abazi, 2014; Makri et al., 2014; Fiala and Havranek 2017) we investigate how NPLs are influencing the profitability, solvency or the macroeconomic evolution. Whereas the sustainability of European banking sector is measured by bank - related and macroeconomic variables, economic growth is explained by the same metrics as well as the profitability. In addition, lagged variables were added but in a more customized way if we compare to Dimitrios et al. (2016). Third, our robust results are suggesting the need to implement a new set of valid and appropriate policies for all Euro Zone countries.

Our findings are in line with the existing results investigating credit risk determinants among EU members, but also reveal new insights regarding the explanatory power of bank-related and macroeconomic variables in relation to risk management. As mentioned earlier, the current risk models underestimate the potential losses. However, we propose adjustments on the existing regulatory capital amounts. More to the point, according to our results, taking regulatory actions should be decided in accordance with business cycles and stock exchange market evolution. The remaining of this paper is organized as follows: the next section explores the methodology and the data. The results are in Section 3, 
while the last section of this paper includes conclusions and policy recommendations for European Banking Authorities.

\section{Materials and Methods}

\subsection{Methodological aspects}

Many empirical studies devoted to investigating financial stability across EU have obtained the results based on Generalized Method of Moments (GMM) proposed by Arellano and Bover (1995). This method has become very popular across researchers mainly because it offers a tractable way to work with panel data characterized by a smaller number of cross sections over a large period of time. However, in our situation, the GMM estimator is not recommended given the data characteristics. For this reason we use a standard OLS model. We considered both fixed and random effects and we decided to provide the final results after computing the Hausman test of Hausman and Taylor (1981). The equation that describes the Pooled OLS was expressed by Baltagi (2005) as follows:

$$
y_{i t}=\alpha+X_{i t}^{v} \beta+u_{i t} i=1, \ldots, N ; t=1_{s, \ldots,} T \text {, }
$$

Where $i$ represent the banking system around European Union, t denotes time. Using $i$ as subscript, we mentioned a specific member of cross - section dimension. Furthermore, having $t$ as subscript we presented a specific moment of time - series dimension. The intercept used in fixed effect models is $\alpha, \beta$ is the vector of coefficients for explanatory variable, $X_{i t}$ indicates the $i^{\text {th }}$ observation on $\mathrm{K}$ explanatory variables. The error component can be represented as follows:

$$
u_{i w}=\mu_{i}+1_{i w}
$$

Where ${ }^{\mu_{i}}$ the unobservable is individual-specific effects and $\vartheta_{i t}$ indicates the remainder disturbance. In a matrix representation, the equation (1) can be expressed as follows:

$$
y=\alpha 1_{w T}+X \beta+u=7 \delta+u_{\text {, }}
$$

Where $\mathrm{y}$ is $N T \times 1, \mathrm{X}$ is $N T \times K, Z=\left[1_{N T}, X\right], \delta^{*}=\left(a^{*}, \beta^{*}\right)$ and ${ }^{1} \times{ }^{N}$ represents the vector of ones having a NT dimension. We used the Hausman test to determine which effects should be included in our final model. In our cases, the decisions were made in favor of the fixed effect models. The fixed parameters given by ${ }^{\mu_{i}}$ are estimated alongside the remainder disturbances $\vartheta_{i t}$ which are independent and identically distributed. The explanatory variables $X_{\text {it }}$ are independent of $\theta_{\text {it for }}$ all $\mathrm{i}$ and $\mathrm{t}$. When fixed effects are considered, the model presented in Eq. (3) can be written as:

$$
y=\alpha 1_{N T}+X \beta+Z_{\mu} \mu+\vartheta=Z \delta+Z_{\mu} \mu+\vartheta \text {, }
$$

We perform the Ordinary Least Squares for Eq. (4) and we receive the estimations of $\tilde{\beta}$, the explanatory variables vector, which is given by:

$$
\begin{aligned}
& \widetilde{\beta}=\left(X^{*} Q X\right)^{-1} X^{*} Q y_{s} \\
& \text { with }^{\text {var }(\tilde{\beta})=\sigma_{\vartheta}^{2}\left(X^{\prime} Q X\right)^{-1}=\sigma_{\vartheta}^{2}\left(\widetilde{X}^{*} \tilde{X}\right)^{-1}} .
\end{aligned}
$$

The robustness of the results estimated based on Eq. (5) is determined using two different approaches. The first one is proposing a different specification for the covariates. We intend to obtain similar coefficients as in the baseline model when different measures (banking or macroeconomics) are included in Eq. (4). The second option of testing the results is to use different subsamples extracted from the original one.

\subsection{Data}

The data sample is built using banking and macroeconomic information from all 28 European Union members at an aggregate level during nine years, from 2008 and 2016. The banking data is collected from European Central Bank's database and official websites of local banking authorities. The source of data for macroeconomic and stock exchange markets is World Bank's database. The geographic area is selected using the evolution of banking risk over the last decade. The European continent was the most affected by the last financial crises in terms of non - performing loans and losses recorded by banks. The period is also 
relevant since it includes both crisis and post crisis periods. The variables used are in accordance with the existing literature and a large variety of them was selected. The initial list of indicators is divided under the following categories:

- Bank - related: Non - Performing Loans Ratio (NPLs), Return on Equity (ROE), Return on Assets (ROA), Cost to Income Ratio (CIR), Net Interest Income Ratio (NII), Loan - to - Deposit Ratio (LTD), Capital Adequacy Ratio (CAR), TIER 1 Capital Ratio (TIER1), Capital to Assets Ratio (CAsR);

- Macroeconomic: Economic Growth (EG), Budget Deficit (BD), Unemployment Rate (UNMP), Inflation Rate (INF), Gross Capital Formation ratio (GCF), Gross Savings ratio (GS);

- Stock Exchange Market: S\&P Global Equity Index.

Usually, when we apply Panel OLS method, all the variables that are included in Eq. (4) should be independent and stationary, in order to avoid spurious regressions. We check these two characteristics using specific tests for panel data. We remove from our analysis variables like ROA, CAR, INF and GS due to correlations reasons. In order to test the stationary, four tests are followed: (Levin et al. 2002; Im et al., 1997) and two Fisher type tests. This way we can also perform a robustness check. We select nine of them to become part of OLS regressions after applying the aforementioned tests. A detailed description regarding the remaining variables is presented in Table S1.

Table 1. Variable definition

\begin{tabular}{|c|c|c|}
\hline Variable & Category & Description \\
\hline $\begin{array}{l}\text { Tier } 1 \text { Ratio (Tier1) } \\
\text { Non - Performing Loans } \\
\text { Ratio (NPLs) } \\
\text { Return on Equity (ROE) } \\
\text { Cost to Income Ratio (CIR) } \\
\text { Net Interest Income Ratio (NII) } \\
\text { Capital to Assets Ratio (CAsR) }\end{array}$ & Bank - Related & $\begin{array}{l}\text { The ratio of bank's core equity capital to total risk - } \\
\text { weighted assets } \\
\text { The ratio of unpaid loans for a period of more than } 90 \text { days } \\
\text { to total loans } \\
\text { Net profit to Total Equity } \\
\text { Operational Expenses to Operational Income } \\
\text { Net interest income divided by total assets } \\
\text { The ratio of equity to total assets }\end{array}$ \\
\hline $\begin{array}{l}\text { Economic Growth (EG) } \\
\text { Budget Deficit (BD) } \\
\text { Gross Capital Formation (GCF) }\end{array}$ & Macroeconomic & $\begin{array}{l}\text { The evolution of Gross Domestic Product (GDP) } \\
\text { Budget Deficit to GDP } \\
\text { Gross Capital Formation to GDP }\end{array}$ \\
\hline S\&P Global Capital Index (S\&P Index) & Stock Exchange & Stock Exchange Prices evolution \\
\hline
\end{tabular}

Table 2. Descriptive statistics for panel data

\begin{tabular}{lcccccccccc}
\hline & TIER1 & NPLS & ROE & CIR & NII & EG & CAsR & BD & GCF & S\&P \\
\hline Mean & 14.65 & 7.80 & 1.12 & -58.75 & 1.89 & 0.84 & 10.34 & -3.29 & 21.42 & -3.24 \\
Median & 13.73 & 4.89 & 4.95 & -55.65 & 1.73 & 1.48 & 7.44 & -2.75 & 21.08 & 0.00 \\
Max. & 52.18 & 48.68 & 33.23 & -18.67 & 4.26 & 25.56 & 71.88 & 4.57 & 36.97 & 76.73 \\
Min. & 5.73 & 0.15 & -100.83 & -412.21 & 0.52 & -14.81 & -0.59 & -32.03 & 9.82 & -73.02 \\
Std. Dev. & 0.06 & 0.08 & 0.17 & 0.26 & 0.01 & 0.04 & 0.12 & 0.04 & 0.04 & 0.29 \\
Skewn. & 3.16 & 2.39 & -3.50 & -10.64 & 0.67 & -0.04 & 4.26 & -2.61 & 0.42 & -0.30 \\
Kurt. & 17.23 & 10.30 & 17.49 & 142.07 & 2.68 & 11.91 & 21.08 & 18.44 & 4.46 & 3.07 \\
JB & 2547 & 799 & 2718 & 207823 & 19.97 & 833 & 4195 & 2788 & 29.92 & 3.88 \\
Prob. & 0.00 & 0.00 & 0.00 & 0.00 & 0.00 & 0.00 & 0.00 & 0.00 & 0.00 & 0.14 \\
S.Sq. Dev. & 0.98 & 1.64 & 7.50 & 16.79 & 0.02 & 0.36 & 3.55 & 0.33 & 0.42 & 21.37 \\
Obs. & 252 & 252 & 252 & 252 & 252 & 252 & 252 & 252 & 252 & 252 \\
\hline
\end{tabular}

Legend: Mean, Median, Max., Min. are expressed in percentages (\%); Max. represents the maximum of sample; Min. indicates the minimum of sample; Skwen. is the skewness statistic; Kurt. Is the kurtosis statistic; S.Sq.Dev represents the Sum of Squared Deviation; JB is the Jarque Bera statistic.

A descriptive statistics for the panel data can be seen in Table S2. Most of our distributions are not normal. The only exception is the S\&P index which follows all conditions of a normal distribution with a negative mean of $-3.24 \%$ and 0.29 standard deviation. With negative asymmetry, we have return on equity, cost to income ratio, economic growth, and budget deficit. However, with positive asymmetry we identify TIER1 ratio, non - performing loans ratio, net interest income ratio, capital to assets ratio, and gross capital formation ratio. 


\section{Results}

\subsection{Results}

An important input to the existing literature brought by the present study is the multi- perspective analysis of banking risks alongside with a detailed description regarding the relations between bankrelated indicators, macroeconomic ones and the stock exchange index. After filtering in the previous section the variables to be included in the models, by taking into consideration only stationary and noncorrelated indicators, we estimate eight regressions. Four of them include only current values, while the remaining ones allow for different lags to estimate the current level of risk and performance in the banking industry. In conclusion, the following models are estimated:

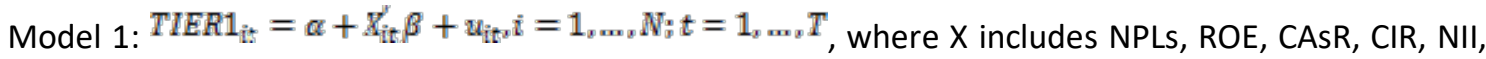
$E G, B D, G C F$, and S\&P Index.

Model 2: $R O E_{\mathrm{it}}=\alpha+X_{\mathrm{it}}^{\prime} \beta+u_{i t}, i=1_{s, n} N_{;} t=1_{s, n} T$, where X includes NPLs, TIER1, CIR, NII, EG, BD, GCF, and S\&P Index.

Model 3: $N P L s_{i t}=a+X_{i t}^{\prime} \beta+u_{i t}, i=1, \ldots, N ; t=1, \ldots, T$, where X includes TIER1, ROE, CIR, NII, EG, BD, GCF, and S\&P Index.

Model 4: $E G_{\text {it }}=\alpha+X_{i t}^{\prime} \beta+u_{i t} i=1_{s, n} N_{s} t=1_{s \ldots s} T$, where X includes NPLs, ROE, CIR, NII, TIER1, BD, GCF, and S\&P Index.

Model 5: TIER1 $_{\text {it }}=\alpha+X_{\text {it }}^{r} \beta_{t}+Y_{i t-1}^{r} \beta_{t-1}+u_{i t}, i=1, \ldots, N ; t=1, \ldots, T$, where $\mathrm{X}$ includes EG, GCF and $\mathrm{Y}$ includes TIER1(-1), NPLS(-1), ROE(-1), CAsR(-1), CIR(-1), NII(-1), BD(-1), and S\&P Index(-1).

Model 6: $R O E_{i t}=\alpha+X_{i t}^{\prime} \beta_{t}+Y_{i t-1}^{s} \beta_{t-1}+u_{i t}, i=1, \ldots s, N_{i} t=1_{s, n} T$, where $\mathrm{X}$ includes TIER1, CIR, EG, GCF, and S\&P Index and Y includes NPLs(-1), ROE(-1), NII(-1), BD(-1).

Model 7: $N P L s_{i t}=\alpha+X_{i t}^{y} \beta_{t}+Y_{i t-1}^{s} \beta_{t-1}+u_{i t}, i=1, \ldots, N ; t=1_{s, n} T$, where $X$ includes NII, BD, GCF and $Y$ includes NPLS(-1), TIER1(-1), ROE(-1), CIR(-1), EG(-1), and S\&P Index(-1).

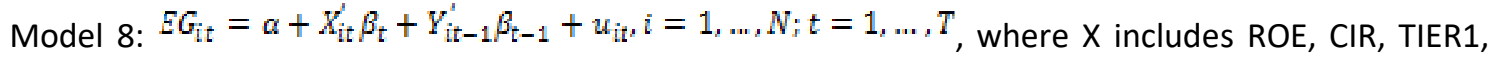
$B D$, and $Y$ includes EG(-1), NPLs (-1), NII(-1), GCF(-1), and S\&P Index(-1).

When establishing these specifications, four different perspective were used: with Model 1 and Model 5 we determine the evolution of systemic solvency indicator for the banking activity; with Model 2 and Model 6 we take into account the profitability of the banking activities; with Model 3 and Model 7 - the evolution of credit risk by using NPLs was studied while with the Model 4 and Model 8 - the macroeconomic evolution. Each time, we include all other variables among covariates. This way we can compare the impact within these views.

\subsubsection{Solvency evolution of European banking systems}

Solvency represents the ability of a certain bank to complete its long-term financial obligations. The continuous monitoring of this indicator is crucial when it comes to surviving in a certain business, since it reveals a bank's ability to continue operations into the foreseeable future. For short term, we can consider liquidity as proxy for the power of banking systems. The solvency indicator used in Models 1 and 5, TIER 1 was intensively used in the literature since it takes into account both the level of main components of equity and the risk-weighted assets. From an economic perspective, an increase of TIER 1 indicates a better administration of the portfolio and a good stability of the system. Starting from this premise, we can explain the empirical findings which are reported in Table 3.

In Model 1, where we analyze how banking solvency is explained, we found statistically significant the CasR ratio, the banking activity ratio and the macroeconomic variables: economic growth and gross capital formation ratio. Between CAsR and TIER 1 there is a positive sign which is statistically significant at 99\% level. The economic growth represents a boost for the economy and a positive sign for the macroeconomic evolution. The direct relationship offered by the estimated coefficient can be due to the reduction of risk - weighted assets caused by an increase of the goodness of existing clients. Moreover, NII and GCF have negative impacts on TIER 1. 
In Model 5 we also include a series lagged variables and, as an observation, the number of significant coefficients has increased in comparison with Model 1 . Moreover, the adjusted R - squared value or the FStatistics are greater in Model 5. Following data from Table S3, we can observe that AIC, BIC, and RSS are lower than in Model 1, fact that reveals the superiority in terms of explanatory power for Model 5 . In this case, the lagged TIER 1 is also relevant with a positive relationship with the current status of solvency ratio. This remark sustains the tight control hypothesis of Louzis et al. (2012) on which group is putting pressure on their members to follow restrictive rules in terms of banking solvency. An increasing level of Non Performing Loans will determine reactions from Banking Authorities of European Central Bank by adding additional capital buffers. This happened in 2010, when introducing a new BASEL agreement in Europe simultaneous with the NPLs faced the biggest values over the past 30 years. Gross Capita Formation in economy is established also by accounting the level of banking capital and, in most of the EU countries this sector contributes a lot to the general evolution of economy. Increases in banking performance and bigger profits will determine reductions of capital because of strong portfolios and the low earnings of equity. Banks will invest more in risky assets and will decrease the level of equity, especially when the economy is growing.

\subsubsection{Profitability evolution of European banking systems}

In many papers, banking profitability is analyzed from a cost - benefit perspective. In terms of cost, the researchers are using risks, especially the level of existing or potential losses. Our focus on this paper is to use similar models by testing the evolution of different important bank - related or macroeconomic indicators. Models 2 and 6 are built the same way as previous ones, the concept of profitability being tested in those cases. Results reflect the direct impact of the significant variables in Model 2, because all of them determine positive signs in economy and banking activity.

For Model 6, with only one exception given by the lagged budget deficit, all variable are statistically significant. The lagged Net Interest Income ratio has a negative influence on current profitability of the banking system, mainly because the periods used in our sample are characterized by large losses due to high levels of provisions and risky portfolios. A negative relationship found in literature by (Dimitrios et al., 2016; Erdinç and Abazi, 2014; Louzis et al., 2012; Makri et al., 2014) between NPLs and ROE is confirmed by the second model's estimations. However, Model 6 reflects a direct impact on banking profitability of the previous year NPLs. This is happening because the authorities are trying to follow the rules imposed by BASEL III and they are also using national policies to reduce the level of NPLs, especially in the last part of the period. In the case of banking profitability, we do not decide on a better model because the results remain the same when we perform some goodness of fit tests. Also, the relevance of lagged variables is found for ROE, NPLS, and NII and the rest from Model 6 are from current year.

\subsubsection{Credit risk evolution of European banking systems}

Credit risk represents the most important banking risk according to Răduțu and Pop (2016) and for this reason it still remains a fascinating topic in banking literature. The results of Models 3 and 7 for credit risk, following as measure NPLs, as (Dimitrios et al., 2016; Makri et al., 2014) and are highlighted in Table S3. Both linear models express the determinants of NPLs for European banking systems, but from the beginning we can remark the superiority of Model 7, which contains lags. The explanatory vector previously used in Model 7 indicates in proportion of 93,5 the credit risk dynamic. The goodness of fit tests indicates no - unit root existence at $1 \%$ level of confidence and the level of RSS, AIC and BIC are lower for this option in comparison to current variables only. As we expected, the level of NPLs is determined positively by the previous year ratio of non - performing loans because the portfolio adjustments are not done that fast and this operation implies ALCO decisions, restructuring, selling existing assets and so on. We have found a reverse relationship between ROE and NPLs, validated by (Dimitrios et al., 2016; Louzis et al., 2012; Makri et al., 2014). Between the evolution of economy and credit risk we identify reverse relationships for previous year economic growth, current budget deficit and gross capital formation. The evolution of macroeconomic factors is validated by Fofack (2005), Jimenez and Saurina (2006). An increase of stock exchange market prices will determine more revenues for listed companies and, in this case, the goodness 
of them will be higher, being capable of returning their debts. For this reason, the coefficient of S\&P Index is negative and equal to -0.021977 under $99 \%$ probability.

\subsubsection{Macroeconomic evolution of European banking systems}

In this last case, the selected regression is Model 8, having stronger determination of EG evolution, almost $60 \%$. At the same time F-Statistics is twice than the one reported for Model 4 . The level of RSS, AIC and BIC statistics are also in favor of Model 8. The estimation of GDP evolution using lags reveals the positive relationship between the lagged GDP and its current level. As we have previously shown, the EG from last year determines a decrease of NPLs. The same sign was found in this case and in both of them, the statistically relevance is missing. The Gross Domestic Product can be calculated using two different perspectives: expenses and revenues. The consumption, governmental expenses, investments and the net result of export are the components of GDP within expenses approach. The taxation, the savings and consumption are part of revenues calculation. The previous year gross capital formation implies a reverse evolution of the EG because the prices of fixed assets or investments followed a negative trend during the period. Positive signs for economy were the increase of stock market prices suggested also by Enciu and Cioaca (2016), a good profitability of banking systems, a reduction operational costs ration to income or better capitalization of banks.

Table 3. Estimations of all computed panel models

\begin{tabular}{|c|c|c|c|c|c|c|c|c|}
\hline & Model I & Model II & Model III & Model IV & Model V & Model VI & Model VII & Model VIII \\
\hline Dep. Var. & TIER 1 & ROE & NPL & EG & TIER1 & ROE & NPL & EG \\
\hline Ind. Var. & Coef. & Coef. & Coef. & Coef. & Coef. & Coef. & Coef. & Coef. \\
\hline $\mathrm{NPL}$ & -0.0224 & -0.1530 & & 0.0441 & & & & \\
\hline ROE & 0.0038 & & -0.0170 & $(0.0778)^{* * *}$ & & & & $(0.0521) * * *$ \\
\hline TIER 1 & & $(0.3688)^{*}$ & 0.0119 & $(0.1766)^{* * *}$ & & $(0.3914)^{*}$ & & $(0.0714)^{*}$ \\
\hline EG & $(0.1815)^{* *}$ & $(1.4049) * * *$ & 0.0883 & & 0.0108 & $(1.2797)^{* * *}$ & & \\
\hline CASR & $(1.4097)^{* * *}$ & & & & & & & \\
\hline $\mathrm{NII}$ & $(-3.1830)^{* * *}$ & 1.6956 & $(3.3616)^{* * *}$ & -0.4094 & & & $(2.1547)^{* * *}$ & \\
\hline $\mathrm{CIR}$ & 0.0118 & $(0.1234)^{* * *}$ & -0.0132 & $(-0.0359)^{* * *}$ & & $(0.1135)^{* * *}$ & & $(-0.0176)^{*}$ \\
\hline $\mathrm{BD}$ & -0.0030 & 0.5097 & $(0.3927)^{* * *}$ & $(0.3758)^{* * *}$ & & & -0.0734 & $(0.2468)^{* *}$ \\
\hline GCF & $(-0.3411)^{* * *}$ & $(1.6939)^{* * *}$ & $(-1.2434)^{* * *}$ & 0.0406 & $(0.2314)^{*}$ & $(2.1588)^{* * *}$ & $(-0.4641)^{* * *}$ & \\
\hline S\&P Index & -0.0056 & $(0.1381)^{* * *}$ & -0.0047 & $(-0.0264)^{* * *}$ & & $(0.1836)^{* * *}$ & & \\
\hline NPL(-1) & & & & & $(0.0903)^{*}$ & $(0.5469)^{* * *}$ & $(0.7804)^{* * *}$ & -0.0121 \\
\hline $\mathrm{ROE}(-1)$ & & & & & -0.0201 & $(0.1682)^{* * *}$ & $(-0.0295)^{* * *}$ & \\
\hline TIER 1(-1) & & & & & $(0.5907)^{* * *}$ & & $(-0.0829)^{*}$ & \\
\hline$E G(-1)$ & & & & & & & -0.0697 & $(0.1946)^{* * *}$ \\
\hline CASR(-1) & & & & & $(0.4263)^{* * *}$ & & & \\
\hline NII $(-1)$ & & & & & $(-2.8117)^{* * *}$ & $(-8.2386)^{* *}$ & & 0.9266 \\
\hline $\operatorname{CIR}(-1)$ & & & & & 0.0002 & & 0.0101 & \\
\hline $\mathrm{BD}(-1)$ & & & & & -0.0404 & -0.4070 & & \\
\hline $\operatorname{GCF}(-1)$ & & & & & & & & $(-0.4206)^{* * *}$ \\
\hline S\&P Index(-1) & & & & & -0.0114 & & $(-0.0220)^{* * *}$ & $(0.0469)^{* * *}$ \\
\hline \multicolumn{9}{|c|}{ Goodness of fit tests } \\
\hline $\begin{array}{ll}\text { Adjusted } & \text { R- } \\
\text { squared } & \end{array}$ & 0.7254 & 0.4439 & 0.7181 & 0.3665 & 0.7799 & 0.5061 & 0.9353 & 0.5947 \\
\hline F - Statistic & $(19.4206)^{* * *}$ & $(6.7236)^{* * *}$ & $(19.2714)^{* * *}$ & $(5.1490) * * *$ & $(22.3548)^{* * *}$ & $(2.9108)^{* * *}$ & $(90.5750)^{* * *}$ & $(10.0908) * * *$ \\
\hline RSS & 0.2316 & 3.5888 & 0.3984 & 0.1988 & 0.1655 & 2.9108 & 0.0845 & 0.1161 \\
\hline AIC & -3.8606 & -1.1280 & -3.3262 & -4.0215 & -4.0332 & -1.1750 & -4.7146 & -4.3965 \\
\hline $\mathrm{BIC}$ & -3.3424 & -0.6238 & -2.8220 & -3.5173 & -3.4545 & -0.6115 & -4.1510 & -3.8330 \\
\hline
\end{tabular}

\subsection{Robustness of results}

In this section we check our results against a series of robustness checks. For this reason, we tested our results using two different approaches. The first approach implies building four different models based on the same methodology. Following it, we presented relationships between all considered variables. Through this perspective, the previous findings are correlated from one model to another, even if the dependent variable is changing between the four models. To sustain our conclusion, a series of correlations are exposed below. Firstly, we found that in Model 1, EG has a positive and statistically significant impact on TIER 1 with a coefficient of 0.1815 and the same evolution is identified in Model 4 , where TIER 1 has a coefficient of 0.1766 . Secondly, a similar situation is discovered also in lagged models, where ROE has an implication on the evolution of EG with $99 \%$ probability. Moreover, with a direct sense in both cases from ROE to EG and reverse, the estimated coefficients are 0.0521 for ROE and 1.2797 for EG. Further, we reached similarities in t moment of variables models as follows: ROE and NPLS in Models 2 and 4, NPLs and 
$E G$, these having no statistically significance. As a final remark on this approach, it is confirmed as wellknown method in the literature for findings testing. This methodology represents a changing of the variables with similar definitions or impact within the models.

Second approach treated by the current paper is to select a sample from the initial database, to prove that evidences are relevant for the existing literature. For this purpose, we extracted the sample of all Euro Zone countries and applied the same regressions from Section 3.1. The new data sample contains 189 observations from 21 European countries. Further, we computed this approach for models with ROE, NPLs and EG as dependent variables, because TIER 1 was not found stationary for Euro Zone countries. Following the methodological line, we discovered that coefficients have the same sign and significance in all computed models. Moreover, in most of the cases, the level of confidence is the same between our findings and robustness models.

As a results of our robustness testing activity done through different perspectives, we can conclude on a relevance of our findings for the existing banking risk models at systemic level in European Union. More, all results of this robustness are exposed in Table 4.

Table 4. Robustness check

\begin{tabular}{|c|c|c|c|c|c|c|c|}
\hline ROE: OLS & Coef. & OLS with lags & Coef. & ROE: OLS & Coef. & OLS with lags & Coef. \\
\hline & & $\mathrm{ROE}(-1)$ & $(0.1648)^{* *}$ & & & $\mathrm{ROE}(-1)$ & $(0.1682) * * *$ \\
\hline NPL & -0.0325 & NPL(-1) & $(0.7688)^{* * *}$ & NPL & -0.1530 & NPL(-1) & $(0.5469)^{* * *}$ \\
\hline NII & 2.8395 & NII(-1) & $(-12.3337)^{* * *}$ & $\mathrm{NII}$ & 1.6956 & NII(-1) & $(-8.2386)^{* * *}$ \\
\hline CIR & $(0.1014)^{* *}$ & $\mathrm{CIR}$ & $(0.1092)^{* *}$ & $\mathrm{CIR}$ & $(0.1234)^{* *}$ & $\mathrm{CIR}$ & $(0.1135)^{* * *}$ \\
\hline EG & $(1.6564)^{* * *}$ & EG & $(1.4601)^{* * *}$ & EG & $(1.4049)^{* * *}$ & EG & $(1.2797)^{* * *}$ \\
\hline BD & 0.8173 & $\mathrm{BD}(-1)$ & -0.2743 & $\mathrm{BD}$ & 0.5097 & $\mathrm{BD}(-1)$ & -0.4070 \\
\hline GCF & $(1.7493)^{* * *}$ & GCF & $(2.2786)^{* * *}$ & GCF & $(1.6939)^{* * *}$ & GCF & $(2.1588)^{* * *}$ \\
\hline S\&P Index & $(0.1485)^{* * *}$ & S\&P Index & $(0.1712)^{* * *}$ & S\&P Index & $(0.1381)^{* * *}$ & S\&P Index & $(0.1836)^{* * *}$ \\
\hline \multirow[t]{2}{*}{ NPL: OLS } & Coef. & OLS with lags & Coef. & ROE: OLS & Coef. & OLS with lags & Coef. \\
\hline & & NPL(-1) & $(0.7875)^{* * *}$ & & & NPL(-1) & $(0.7804)^{* * *}$ \\
\hline NII & $(4.1262)^{* * *}$ & NII & $(1.5319)^{*}$ & $\mathrm{NII}$ & $(3.3616)^{* * *}$ & NII & $(2.1547)^{* * *}$ \\
\hline ROE & -0.0035 & $\operatorname{ROE}(-1)$ & $(-0.0349)^{* * *}$ & ROE & -0.0170 & $\operatorname{ROE}(-1)$ & $(-0.0295)^{* * *}$ \\
\hline CIR & -0.0167 & $\operatorname{CIR}(-1)$ & 0.0098 & $\mathrm{CIR}$ & -0.0132 & $\operatorname{CIR}(-1)$ & 0.0101 \\
\hline EG & 0.0446 & $E G(-1)$ & -0.0514 & EG & 0.0883 & $E G(-1)$ & -0.0697 \\
\hline BD & $(0.4456)^{* * *}$ & $\mathrm{BD}$ & -0.0858 & $\mathrm{BD}$ & $(0.3927)^{* * *}$ & $B D$ & -0.0734 \\
\hline GCF & $(-1.3342)^{* * *}$ & $\mathrm{GCF}$ & $(-0.4807)^{* * *}$ & GCF & $(-1.2434)^{* * *}$ & $\mathrm{GCF}$ & $(-0.4641)^{* * *}$ \\
\hline S\&P Index & -0.0058 & S\&P Index(-1) & $(-0.0233)^{* * *}$ & S\&P Index & -0.0047 & S\&P Index(-1) & $(-0.0220)^{* * *}$ \\
\hline \multirow[t]{2}{*}{ EG: OLS } & Coef. & OLS with lags & Coef. & ROE: OLS & Coef. & OLS with lags & Coef. \\
\hline & & $E G(-1)$ & 0.0631 & & & $E G(-1)$ & $(0.1946)^{* * *}$ \\
\hline NPL & 0.0225 & NPL(-1) & -0.0709 & NPL & 0.0441 & NPL(-1) & -0.0121 \\
\hline NII & -0.0417 & NII(-1) & -0.2900 & $\mathrm{NII}$ & -0.4094 & NII(-1) & 0.9266 \\
\hline ROE & $(0.0908)^{* * *}$ & ROE & $(0.0878)^{* * *}$ & ROE & $(0.0778)^{* * *}$ & ROE & $(0.0521)^{* * *}$ \\
\hline $\mathrm{CIR}$ & $(-0.0376)^{* * *}$ & $\mathrm{CIR}$ & $(-0.0275)^{* *}$ & $\mathrm{CIR}$ & $(-0.0359)^{* * *}$ & $\mathrm{CIR}$ & $(-0.0176)^{*}$ \\
\hline BD & $(0.4437)^{* * *}$ & BD & $(0.3354)^{* * *}$ & $\mathrm{BD}$ & $(0.37578)^{* * *}$ & $\mathrm{BD}$ & $(0.2468)^{* * *}$ \\
\hline GCF & -0.0535 & GCF $(-1)$ & $(-0.5916)^{* * *}$ & GCF & 0.0406 & GCF $(-1)$ & $(-0.4206)^{* * *}$ \\
\hline S\&P Index & $(-0.0184)^{*}$ & S\&P Index & $(-0.0338)^{* * *}$ & S\&P Index & $(-0.0264)^{* * *}$ & S\&P Index $(-1)$ & $(0.0469)^{* * *}$ \\
\hline
\end{tabular}

\section{Conclusions}

In this paper we proposed a multi - perspective approach for testing the banking sustainability in Europe, alongside the determination of some relationships between economic cycles, stock exchange market evolution and banking risks. We consider four different measures: TIER 1 Capital Ratio, Return on Equity, Non - Performing Loans Ratio and Economic Growth. This way, we fill the existing gap in the literature by taking into account this multi - view and comparing the results between different panel OLS regressions. At the same time, with a large variety of data, including all EU countries between 2008 and 2016 , the results remain robust regardless the stress tests we implement. Our results are pointing out some major limitation of the current risk models to estimate efficiently the main causes that generate losses in European banking systems. From a policy making perspective, we are suggest an increase for the capital level for covering banking risks. Moreover, according to our results the major impact of capital markets must be considered in every model attempted to study risk and profitability nexus.

The findings imply major policy changes, especially during the crisis and right after crisis periods. The national and European authorities should consider this multi - approach for evaluating the banking risk since some relevant decisions could be made based on the similar significance and signs between the 
aforementioned models. Keeping in mind the impact of previous periods on the current evolution of banking risk and economy, regulators must decide via which channels to act. The efficiency of every channel might be determined using the paper's approach. For sure, a non-linear approach can offer better results and examples exist in literature, but those are focused on a single topic. For example, Pop et al. (2018) offered proposals to National Banks or local authorities to split the entities in different homogenous groups. By doing as presented, the policies will be adaptable to each type of group and applied in accordance to different critical values of threshold indicators. In most cases, these are determined by the list of regulated calculations within the banking industry. This type of development consists in further research of the current paper: an application of non - linear models to a multi - perspective of banking risks and economy.

\section{References}

1. Anghelache, G., Oanea, D.C. (2014). Main Romanian Banks' Systemic Risk during Financial Crisis: A COVAR Approach. The Review of Finance and Banking, 06, 2, 69-80.

2. Anghelache, G., Oanea, D.C. (2016). Romanian Commercial Banks' Systemic Risk and Its Determinants: A CoVAR Approach, International Journal of Academic Research in Accounting, Finance and Management Sciences. Vol. 6, No. 3, July 2016, pp. 96-109.

3. Arellano, M., Bover, O. (1995). Another look at the instrumental variable estimation of errorcomponents models, Journal of Economics. 68, 29-51.

4. Baltagi, H.B. (2005). Econometric Analysis of Panel Data, in John Wiley \& Sons, Ltd, Third Edition.

5. Barbu, T.C., Boitan, I. (2018). Confidence in European Retail Banking: Assessing Relationship with Economic Fundamentals. Ekonomicky Casopis, 66, 2, $181-198$.

6. Brad. L., Muntenu, A., Dobre, F., Ciobanu, R, (2013). Quantifying the Romanian Banks' Performance and the Impact of Audit Inspections upon Them when IFRS Reporting Standards is Used. In Proceedings of the 8th International Conference Accounting and Management Information Systems, AMIS 2013, pp 271-283. Available online: http://www.cig.ase.ro/amis2013/fisiere/amis2013.pdf (accessed on 22 December 2018).

7. Cepoi, C.O., Toma, F.M. (2016). Estimating Probability of Informed Trading on the Bucharest Stock Exchange. Finance A Uver-Czech Journal of Economics and Finance, Vol. 66, No. 2, pp. 140-160.

8. Damian, V.C, Cepoi, C.O. (2016). Volatility Estimators with High-Frequency Data from Bucharest Stock Exchange. Economic Computation and Economic Cybernetics Studies and Research, Vol. 50, No. 3, 2016, pp. 247-264.

9. Dimitrios, A., Helen, L., Mike, T. (2016). Determinants of non-performing loans: Evidence from Euro-area countries. Finance Research. Letters, 18, 116-119.

10.Duffie, D., Singleton, K. (2001). Credit Risk. Pricing, Measurement, and Management. Princeton University Press, Princeton and Oxford.

11.Eichler, S., Maltritz, D. (2013). The term structure of sovereign default risk in EMU member countries and its determinants. Journal of Banking and Finance, 37, 1810-1816.

12.Enciu, A., Cioacă, S.I. (2017). Is the Capital Market Important for the Economic Growth in the EU? Annals of Faculty of Economics, 26, 1, $315-324$.

13.Erdinç, D., Abazi, E. (2014) The Determinants of NPLs in Emerging Europe, 2000-2011. Journal of Economics and Political Economy, 1, 112-125.

14.Fiala, T., Havranek, T. (2017). The sources of contagion risk in a banking sector with foreign ownership. Economic Modeling, 60, 108 - 121.

15.Fofack, H. (2005). Nonperforming loans in Sub-Saharan Africa: causal analysis and macroeconomic implications (English). Policy, Research working paper; no. WPS 3769. Washington, DC: World Bank.

16.Gao, Q., Fan, H., Jiang, S. (2019). Macroprudential Regulation for the Chinese Banking Network System with Complete and Random Structures. Sustainability, 11, 69.

17.Ghosh, A. (2015). Banking-industry specific and regional economic determinants of nonperforming loans: Evidence from US states. Journal of Financial Stability, 20, 93-104.

18.Gómez-Fernández-Aguado, P., Parrado-Martínez, P., Partal-Ureña, A. (2018). Risk Profile Indicators and Spanish Banks' Probability of Default from a Regulatory Approach. Sustainability, 10, 1259. 
19.Guidara, A., Lai, V.S., Soumaré, I., Tchana Tchana F. (2013). Banks' capital buffer, risk and performance in the Canadian banking system: Impact of business cycles and regulatory changes. Journal of Banking and Finance, 37, 3373- 3387.

20. Hausman, J.A., and W E Taylor (1981). Panel data and unobservable individual effects. Econometrica, 49:1377-1398.

21.Im, K.S., Pesaran, M.H., and Shin, Y., (1997). Testing for Unit Roots in Heterogenous Panels. DAE, Working Paper 9526, University of Cambridge.

22.Jaradat, M. A., ALkhazaleh, M. H. A. (2018). The Effect of Liquidity, Administrative Efficiency and Capital Adequacy on the Profitability of Jordanian Banks listed on the Amman Stock Exchange, International Journal of Academic Research in Accounting, Finance and Management Sciences, 8 (4): 183-194.

23.Jiménez, G., Lopez, J.A., Saurina, J., (2006). Credit cycles, credit risk, and prudential regulation. International Journal of Central Banking, $65-98$.

24.Kauko, K. (2012). External deficits and non-performing loans in the recent financial crisis. Economic Letters, 115, 196-199.

25.Levin, A., Lin, C.F., Chu, C.S.J., (2002). Unit Root Test in Panel Data: Asymptotic and Finite Sample Properties. Journal of Econometrics, 108, 1-24.

26.Louzis, D. P., Vouldis, A. T., Metaxas, V. L. (2012). Macroeconomic and bank-specific determinants of non-performing loans in Greece: A comparative study of mortgage, business and consumer loan portfolios. Journal of Banking and Finance, 36, 1012-1027.

27.Makri, V., Tsagkanos, A., Bellas, A. (2014). Determinants of Non-performing loans: The case of euro zone. Panoeconomicus, 61, 193-206.

28.Moscu, R.G. (2014). Capital Structure and Corporate Performance of Romanian Listed Companies. International Journal of Academic Research in Accounting, Finance and Management Sciences, Vol. 4, No.1, January 2014, pp. 287-292

29.Murărașu, B., Bobașu, A. (2014). Output Spillovers from Trade and Financial Linkages in Central and Eastern European Countries: A Panel Analysis. The Review of Finance and Banking, 06, 2, 81 - 96.

30.Okegbe, T.O., Eneh, O.M.-R., Ndubuisi, A.N. (2019). Effect of Firm Characteristics on Capital Structure of Deposit Money Banks Listed on Nigeria Stock, International Journal of Academic Research in Accounting, Finance and Management Sciences, 9 (2): 198-210.

31.Pop, I.D., Cepoi, C.O., Anghel, D.G., (2018). Liquidity - threshold effect in non-performing loans. Finance Research Letters, 27, 124-128.

32.Răduțu, A., Pop, I.D. (2016). Decision Models in Romanian Banking Sector after the last World Financial Crisis: An AHP Approach. In Proceedings of the 12th International Scientific Conference E-learning and Software for Education Bucharest, 1543-1551. Available online: https://sgemworld.at/ssgemlib/ spip.php?article2764 (accessed on 22 December 2018).

33.Salas, V., Saurina, J., (2002). Credit risk in two institutional regimes: Spanish commercial and savings banks. Journal of Financial Services Research, 22, 203-224.

34.Umaru, H., Aguda, N.A., Davies, N.O. (2018). The Effects of Exchange Rate Volatility on Economic Growth of West African English-Speaking Countries, International Journal of Academic Research in Accounting, Finance and Management Sciences, 8(4): 131-143.

35. Zhang, X., Li, F., Li, Z., Xu, Y. (2018). Macroprudential Policy, Credit Cycle, and Bank Risk-Taking. Sustainability, 10, 3620 . 